Furman University

Furman University Scholar Exchange

Anthropology Publications

Anthropology

2008

\title{
Chipimpi, Vulgar Clans, and Lala-Lamba Ethnohistory
}

Brian Siegel

Originally published in History in Africa. Volume 35. 2008. p. 439-453. http://journals.cambridge.org/action/ displayJournal?jid=HIA

Verbeek (1987) argues most persuasively that Chipimpi, the mythological first chief of the Lamba mentioned on p. 6 of this paper, is a representation of Yeke king Msiri, who conquered and enslaved the Lamba and neighboring peoples in Katanga from his capital at Bunkeya. Thus the mythological chief Chipimpi is an appropriate target for patricide.

\section{Recommended Citation}

Siegel, Brian, "Chipimpi, Vulgar Clans, and Lala-Lamba Ethnohistory" (2008). Anthropology Publications. Paper 1.

http://scholarexchange.furman.edu/ant-publications/1

This Article (Journal or Newsletter) is made available online by Anthropology, part of the Furman University Scholar Exchange (FUSE). It has been accepted for inclusion in Anthropology Publications by an authorized FUSE administrator. For terms of use, please refer to the FUSE Institutional

Repository Guidelines. For more information, please contact scholarexchange@furman.edu. 


\title{
Chipimpi, Vulgar Clans, and Lala-Lamba Ethnohistory
}

(Corrected version of the paper in Hermine G. De Soto's Culture and Contradiction: Dialectics of Wealth, Power, and Symbol, the Aidan Southall Festschrift, San Francisco: EM Texts, 1992)

\author{
Brian Siegel (Anthropology) \\ Religion Department, Furman University \\ Greenville, SC 29613 \\ brian.siegel@furman.edu
}

Not to be cited or quoted without written permission

Common to the matrilineal peoples of eastern central Africa is their clan system, and the reciprocal joking, or "funeral friendship," relations that exist between clans with figuratively complementary names (Cunnison 1959: 62-71; Richards 1937; Stefaniszyn 1950). This paper, however, focuses on the southeastern Shaba Pedicle, and the anomalous, one-sided joking between the Vulva and (allegedly pubic) Hair clans of the Lala and Lamba chiefs. It suggests that this joking, like the claim that these clans share a common mythical ancestor, is best explained in terms of nineteenth century Lala and Lamba history, and of their competing claims to the Pedicle's easternmost end. This region of Bukanda lies between the Aushi to the north (in Bwaushi), the Lala and Swaka to the east and south (in Ilala and Maswaka), and the Lamba (of Ilamba) to the west. The main distinction between these closely related and adjacent peoples, with their similar customs and languages, is in the histories and traditions of their chiefs.

The bizarre relationship between the chiefly Vulva and Hair clans is not widely known. I only heard of it during my fieldwork in Ilamba. The Lala, like the Lamba, straddle both the Congolese and Zambian sides of the Shaba Pedicle, and the literature on this region in both French and English, is fragmentary and marked by an ahistorical and uncritical acceptance of oral traditions. The Lala are probably best known in relation to Mwana Lesa's Watchtower movement of the 1920s (Verbeek 1977, 1983). Norman Long's Social Change and the Individual (Manchester, 1968) is the only modern ethnography on the Lala, yet this study of the enterprising Jehovah's Witnesses has little to say about their history or clans. Fortunately, Léon Verbeek's Filiation et usurpation (1987) has sorted through the oral and colonial histories, and has paved the way for comparative ethnohistories of the peoples on both sides of the Shaba Pedicle.

\section{II}

The matrilineal peoples of eastern Central Africa share a number of common culture traits (Richards 1939: 16-17; 1950: 221-36). Among these is an assortment of some thirty to forty exogamous clans, each bearing the name of a plant, animal, or some 
other feature of the natural or cultural world. This clan system is common to the matrilineal peoples found between the southern end of Lake Tanganyika and the Luangwa River in the east, and west to the Lualaba and Lunga Rivers. The peoples involved are, in alphabetical order, the Ambo (or Kambonsenga), Aushi, Bemba, Bena Chishinga, Bena Kabende, Bena Mukulo, Bena Ngumbo, Bisa, Kaonde, Lala, Lamba, Lima, Luano, Kazembe's Lunda, southern Lungu, Sanga, Seba, Senga, Swaka, Tabwa, and Unga (Cunnison 1959: 62n; Grévisse 1956: (32) 77-80, (35) 95-97, (38) 120; Richards 1939: 16-17; 1950: 221-22; Slaski 1950: 86; Whiteley 1950: 5). I do not claim that this list is exhaustive. The marital histories I collected suggest that the Lenje and Soli should also be included, and Smith and Dale (1920, vol. 1: 287-98, 308-13) describe very similar clans and joking relations among the Ila.

The same or similar clan names are so widely distributed across the region that they probably predate its current ethnic labels, and the supposed migration of these peoples' ancestors from the western, Luba or Lunda land of "Kola." The claims to Luba origins are most frequently found in Zambia, while those to Lunda origins, as one might expect, are common to the Shaba Pedicle (Verbeek 1987: 164-66, 326-28). Thus the Zambian Lamba claim Luba, while those in Shaba, Lunda origins. Such claims seem to be self-serving assertions of these chiefdoms' antique legitimacy. None of the current ethnonyms are primordial, yet the "Muiza" (Bisa) informants Lacerda encountered during his 1798 journey to Kazembe clearly refer to the hostile "Uemba" and "Mussucuma" (Bemba and Sukuuma, a feisty Fipa subgroup), and to the peaceful "Aramba" (Lamba) and "Ambo" (Burton 1873: 99). Regardless of ethnic identities, people with the same clan name (or referent) are theoretically related. And since every person is considered a "child" of both his mother's and father's matriclans, and a "grandchild" of his mother's father's and father's father's matriclans, a traveling stranger can claim hospitality from a wide network of clan relatives.

But the same clan system also establishes reciprocal partnerships between those whose clan referents stand in relation of symbolic complementarity or interdependence. While church congregations have not completely eliminated the role such "funeral friends" once played in burying each other's dead, the reciprocal baiting between jokingclan partners remains a vital part of everyday life, and one which establishes warm, kinlike relations between relative strangers (Boswell 1969; Epstein 1981: 194-98). Using the language of chiefly master-servant relations, the Iron clansfolk, for example, berate the Grass clan as their "slaves," arguing that iron (knives and hoes) kill grass. The Grass clan, in turn, asserts their superiority on the grounds that grass (thatch) saves iron from being eaten by the rain.

Joking-clan partners abuse one another in ritualized enmity. The very names for these partners - balwani or baali (Lala), balongo (Lamba), or banungwe (Ambo, Aushi, Bemba, and Sanga) - are those for "enemies." Their reciprocal banter entails a licensed disregard for the code of good manners (muchinshi). Thus, while these peoples ordinarily "use a variety of euphemisms when discussing sex relations, and are in particular careful of referring to sex matters when members of different age groups are present" (Richards 1940: 17), joking-clan partners employ amatuka, or vulgar sexual 
insults, to engage in "mutual cursing of the grossest kind" (Stefaniszyn 1950: 291). Lambo (1946: 325) says, "These insults [amatuka] are frequent; they generally call into question the virtue of one's relatives and allude to the private parts of one's maternal ancestry. The Lala possess a very rich vocabulary in this domain." Doke (1931: 77n) offers the following "typical examples" of Lamba amatuka: "Little [but connoting "big"] penis of your mother!" "Little anus of your mother!" "Your little penis!" and "Your little testicle!" As provocations to a fight, such amatuka are punishable offenses against customary law (Doke 1931: 67, 77, 213; Grévisse 1956: (39) 126; Stefaniszyn 1964b: 101). Smith and Dale (1920, vol. 1: 377) say that the Ila must not only avoid references to private parts and natural functions when in mixed company, but should also "avoid the use of words and expressions of the same or similar sound." The compulsive and privileged license between joking-clan partners serves as "a highly efficient ice-breaker" at any social gathering (Cunnison 1959: 70).

III

Of all these joking-clan peoples, however, those along the southeastern Shaba Pedicle actually have clans with vulgar (amatuka) names. I discovered this during the course of my fieldwork when I tried making sense of my informants' common claim that the Bena Mishishi (Hair clan) chiefs of the Lamba and Seba (Lamba offshoots) are somehow related to the Bena Nyendwa (Vulva clan) chiefs of the Lima, Swaka, Lala, and Ambo. Doke (1931: 195) called the latter the "Needle clan," for he, like Stefaniszyn (1954b: 5), was evidently told that they were named for the nyenda, a wooden matmaking needle. I saw no symbolic complementarity between these Hair and "Needle" clan names. And getting no help from my surprised and amused, but evasive, friends, I decided to try eliciting Doke's "Needle clan" translation while interviewing a gregarious Lamba age-mate at his father's old, established village, just inside a Lima chiefdom.

Fishing for phallic symbols, I steered him to the topic of clan names and, in spite of his evasion, that of the Lima chiefs. My indirection failed, for he claimed ignorance of the Lima's chiefly clan and, then, the meaning of its name! So, as his sisters tittered and his father guffawed, I reduced him to an embarrassed silence by asking just what kind of animal the nyendwa (vulva) was.

As matters of good manners (muchinshi) and shame (nsoni), one should never raise sexual issues with one's parents or members of their generation, or with siblings of the opposite sex, so my questions were doubly indecent. The same sexual etiquette is expressed in the social distance between adjacent generations, and social solidarity of alternate ones. (See Watson 1954: 16-23; also Epstein 1981: 200-04; Richards 1940: 1517, 25; Stefaniszyn 1964b: 11-12, 87-88). He suggested that we retire to a neighborhood Chibuku tavern, and, on our way, told me about vulvas and the shame (nsoni) my amatuka had caused him. Doke, by the way, got it straight as well, for the sexual entries in his Lamba Vocabulary are marked with an "M" for amatuka, or "vulgar terms" (Doke 1963: v). 
But the Vulva clan is not the only vulgar clan along the Shaba Pedicle. Here one also finds the Bena Bi or Anus, Bena Mwanso or Penis, and Bena Mubinda or Breechcloth clans. Mwanso properly denotes the male genitals. A Lala told me it was the same as ubwaume, the Bemba term for "virility," "male organs," and, more commonly, "penis." One of Verbeek's (1982: 182) informants, an elderly Lala female, pointed to a billy goat and described it as "that thing dangling down" (kilye ikikolebela $m u$ ). Thus, while Lambo (1946: 248) translates the Bena Mwanso as the "Testicles clan," most call it the Penis clan (Boswell 1969: 281n; Mitchell and Barnes 1950: 50; Munday 1961: xvi; Stefaniszyn 1964b: 5).

The mubinda (or mobinda) of the Bena Mubinda (Breechcloth Clan) is draped over the buttocks, tied around the waist, and is then drawn up between the legs and through the tie in front. While Stefaniszyn (1964a: 16; 1964b: 1) calls it a "loincloth," Lambo (1946: 248) and Verbeek (1987: 355) call it a "cache-sexe," in short, a G-string. In this respect, it may be a euphemism for the bukushi, a small cloth strip suspended front and rear from a woman's beaded waist string (Stefaniszyn 1964a: 16; White Fathers 1954: 46). In the idiom of joking-clan banter with the Anus and Musamba Tree (source of barkcloth) clans, it conceals the vulva (Stefaniszyn 1950: 301).

Smith and Dale (1920, vol. 1: 303), in a list of foreign clans among the Ila, include the "Vulva" (Nyendwa) clan from the "Batema and Walenje," and the "Anus" (Chibanda) and "Vagina" (Ntoto) clans from the "Balamba (Badima)," west of the Lukanga Swamp. While I doubt that the Anus is a Lima ("Badima") clan, chibanda is not "anus" (Ila inyo, Lamba inyenu), but a common term for "evil spirit" or "devil." And since ntoto is the Ila term for "vaginal orifice" (vol. 1: 233), their "Vagina" clan is the same as the Vulva clan.

The Swaka and Lima are not included with the Lala and Ambo here because, while their chiefs are Bena Nyendwa, I have no evidence that they have the Anus, Penis, or Breechcloth clans. Munday (1940: 447; 1950: 25-26, 40-41; 1961: 24-28) claims that both the Swaka and Lima chiefs derive from the Swaka's Mwewa lineage who, after the Lala conquest, changed from the Bena Ng'ona (one of the many Mushroom clans) to the Vulva clan. If true, this may explain the apparent absence of these other vulgar clans among the Swaka and Lima. Having never encountered any reference to the Anus, Penis, or Breechcloth clans in the Lima marital histories I collected, I place no credence in Moffat Thomson's claim (in Brelsford 1965: 50) that the Lima are a Lala offshoot.

These are even more narrowly localized, for they are as specific to the Lala and their Ambo offshoots as the Hair clan is to the Lamba and their Seba offshoots (Stefaniszyn 1964: 1; Verbeek 1987: 326). Thus, of 299 marital histories I collected from the Lamba and Lima areas in Ndola Rural District, fifteen of the seventeen Hair clan spouses came from Lamba chiefs' areas, and ten of the thirteen Vulva clan spouses came from Lima or Lala chiefs' areas. The remaining five spouses - from nearby Lima, Lamba, or Swahili chiefs' areas - were presumably of Lamba or Lima ancestry (Mitchell and Barnes 1950: 50). The Anus clan was never mentioned, but one Lala each had a Penis and Breechcloth father. 
It is futile to ask the origins of these vulgar clans, for all are either attributed to Lesa (God) and Kola, or to the ancestors who broke some prohibition at a funeral, and were then named for the thing responsible for their impropriety (Doke 1931: 182, 193 97). Lambo (1946: 247-48) records just these sorts of just-so stories for the origins of the Anus and Breechcloth clans. According to the less "indecent and scatological" accounts, the Anus clan were cast out of the Vulva clan for breaking the taboo against burying their own clansman (also Munday 1940: 441; 1961: 13). And the Breechcloth clan were outcast from the Blue Monkey clan because their women, while serving beer at a funeral feast, wiped their fingers on their genitals. The Penis clan's origins must be equally indecent, for it is attributed to their members' former prolificacy (also Stephenson 1937: 131).

The one exception to these just-so stories about clan origins appears to be that for the Vulva clan, which is only described by Munday (1940: 440-41; 1950: 3-4; 1961: 7). It seems that two chiefs, Chisenga Mushili and her brother, Malama, left Kola in search of their land. Upon reaching the Itumba Hills, west of Serenje, in the heart of Ilala (Verbeek 1987: 249), they met a woman fetching water. They refused a drink from her gourd, so she urinated into her water pot, and the chiefs bent down and sucked it up. Thus "all changed to the name Nyendwa because they drank water which had come from the loins [tubunda, crotch] of a woman" (Munday 1940: 440-41). This bizarre vulgarity does make some sense, for the drinking of a clanswoman's urine, symbolizing clan solidarity, figures in both the cleansing of burial parties and the ritual curse-removal between estranged clan members (Munday 1961: 7; Stefaniszyn 1964b: 3, 126).

Such stories are not to be taken literally, for they merely reflect the ribald jokingrelations that exist between the Vulva and each of its other mutual and intimately related "sister-clans." Just as the Sorghum and Finger Millet clans share sisterhood (bwanankashi) because their referents are both grains, the Vulva, Anus, and Breechcloth clans are considered such because breechcloths cover vulvas and anuses. The breechcloth is treated as a woman's garment, so the Breechcloth and Penis clans' opposition, like that of the Vulva and Penis clans, is based upon sexual complementarity and "physical dependence." And though the Anus clan says "only wizards do it," the joking between it and the Vulva and Penis clans is based upon the anus being a poor (and proscribed) substitute for the vulva (Stefaniszyn 1950: 299-304).

The Anus is a special sister-clan. Since it originated from the Vulva clan, the two do not intermarry (also Lambo 1946: 247; Munday 1940: 441, 453). Boswell (1969: 281n) reports the existence of an Anus clan chief among the Lala.

The Vulva's sister-clans are mentioned by Boswell (1969: 281n), Munday (1961: xv-xvi, 19), and Stefaniszyn (1964b: 5-6). Among the Ambo, these also include the Bena Nyangu (Bean clan), inasmuch as beans symbolize pubic hair and the clitoris in the neighboring Chisenga's chisungu rites (Stefaniszyn 1964b: 6; Munday 1961: viii). Kankomba (Scraper), the praisename of the Lala chiefs, supposedly derives from a 
version of the Chipimpi myth in which a Vulva clan ancestor scrapes clean the relish pot of beans (nyangu) while his cross-cousin (Kabunda) of the Hair clan works in the clay pit (Munday 1940: 436-38; 1950: 6-7; 1961: 9-10). This again suggests that such vulgar clans are specific to the Lala.

Others claim that the Bena Mishishi, the Hair clan of the Lamba (and Seba) chiefs, is the "Public Hair" clan, and a member of the Vulva clan's set of vulgar sisterclans. The Bena Mishishi are named for the hair of the human head (mishishi), and its members deny that their name is a euphemism or synonym for pubic hair (amaso) (Doke 1931: 194; Stefaniszyn 1964b: 92). Yet this is such an open secret that studies of the Swaka, Lala, and Ambo invariably refer to them as the "Pubic Hair" clan. "Chirupula" Stephenson, who served in Ilamba and Ilala, and was the polygynous husband of a Lala Vulva clanswoman, suggests that the hair clan had a vulgar origin (Stephenson 1937: 131). What is more damning, Verbeek (1987: 29) cites three Lamba sources for the tale that the Hair clan were outcast from the Vulva clan after burying a chief with his pubic hair intact.

To bury a chief with his full crop of public hair would be doubly scandalous. First, when female initiation rites (chisungu) were still practiced, the instruction in wifely duties included that of plucking (later, shaving) the husband's pubic hair and giving it to him for safe burial (Doke 1931: 169; Grévisse 1956: (32) 122; Marchal 1933-34: 125; Stefaniszyn 1964b: 92). The Bemba probably did this too, for the White Father's Dictionary (411) includes the phrase "to shave or depilate pubic hair" (ukusesa maso). Second, given the elaborate (and grisly) care given chiefs by their funeral attendants, it is difficult to see how such pubic hair could have escaped notice. (See Edeme 1944: 87-93; Doke 1931: 186-90; Lambo 1946: 283-85; Marchal 1933-34: 103; and Stefaniszyn 1964b: 52-60). This origin fable, like the "pubic hair" label, is a vulgar insult against the Hair clan.

\section{V}

These supposed links between the Vulva and (pubic) Hair clans are all the more interesting in light of Munday's Western Lala oral traditions, which claim that these clans share a common ancestor in Chipimpi, the first chief of Lamba legend (Munday 1940; 1950; 1961).

The origin of the Lamba's chiefly Hair clan is found in the far more elaborate myth of Chief Chipimpi. It explicitly explains how he lost his people, his head, and his chiefdom to the Hair clan. (The most accessible version of the Chipimpi myth is in Doke's Lamba ethnography [1931: 31-35]. Increasingly more satisfactory versions are those in Doke [1922], Marchal [1936], and Verbeek [1982: 22-120]. The myth is discussed in Siegel [1985] and Verbeek [1987: 9-26]). The Lamba conventionally assign the Hair clan's origins and praisename, Mwansekanda (Mwansa + we $+i k a n d a ?)$, to that episode in which Chipimpi sent both a nephew and his son, Kabunda, into a pit (ikanda) to extract plastering clay. Once done, the nephew accepted and killed a goat. But Kabunda, goaded by his mother, refused to leave the pit until given a person, whom he 
killed, and in whose blood he bathed. This son and future chief thereby declared Chipimpi's people to be the Goat clan, and himself to be one of the Hair clan.

Since the term mwansa denotes an animal's "mane" (Doke 1963: 97) - the long hair on an animal's neck (White Fathers 1954: 519) - this clan's praisename might best be translated as "Mane of the Pit." Mwansa, though, has alternative meanings. It was once a popular personal name, and Verbeek (1987: 14-16) prefers to render it as such. It also appears in an exploit of Kalulu, or Little Hare, the folklore hero in "Mwansa the aimer who aimed at five people with the arrow in his navel" (Doke 1927: 400). This is probably a reference to the epithet mwansa kabinga, a cruel, savage, and proud fellow (Lambo 1946: 342; White Fathers 1954: 510). This too, is consistent with Kabunda's patricidal exploits.

While the myth alone does not support the conventional Lamba belief that Kabunda either seized his victim by the hair, or washed his hair with the victim's blood (Verbeek 1987: 14-16), the Hair clan's identity is consistent with at least two other episodes in the myth. Early in the myth, Chipimpi's newly found wife and Kabunda's mother, Kashanga, introduced his people to fire and, from a plaited hollow in her hair, the seeds of all cultigens. Later, after the episode in the pit, the Goat and Hair clans quarreled and, before separating, divided Kashanga's seeds. But while the Goat clan got those she had secretly roasted, Kabunda and his sister were given the fertile ones. These, again, were concealed in a hollow of plaited hair. So throughout this myth, the mwansa portion of the Hair clan's praisename seems firmly rooted in the hair of the human head (mishishi).

VI

Now most of the Congolese (i.e., Shaban Pedicle) Lala know of Chipimpi/Kipimpi, but deny any links through him to the Lamba chiefs (Verbeek 1987: 247-48). Such claims are specific to the Mushili lineage of Lala chiefs, the family of Vulva clan chiefs who conquered the Lamba of the Bukanda region (Verbeek 1987: 25450) and, under Chief Bwashi, the Swaka of Maswaka. The same lineage continues to rule the Western (Mkushi District) Lala and Ambo (Petauke District) chiefdoms in Zambia. The Eastern (Serenje District) Lala chiefs, however, appear to represent a different lineage (Brelsford 1965: 49-52; Lambo 1946: 235; Munday 1940: 443-52; Stefaniszyn 1964a: 5-9 and 1964b: xx-xxii). Munday's Western Lala-Maswaka version of the Chipimpi myth is clearly linked to the Mushili lineage, for a number of his unnamed informants told him "they had heard their story from one Nkufye, who was storyteller to Chief Bwashi" (Munday 1961: xiv).

It is the Mushili lineage that claim Chipimpi as the ancestor of the Lala, Lamba, and Aushi chiefs. They do so either by having him travel through Bwaushi, or by investing him with additional wives from the clans of the Lala and Aushi chiefs (Verbeek 1987: 232-47). Thus, in Munday's Western Lala traditions, Chisenga Mushili (mentioned previously), an original founder of the Vulva clan, is one of Chipimpi's wives; her daughter crosses the Luapula to marry an Aushi chief of the Wild Pig clan; and her 
daughter's son eventually abandons his uncle's western lands in Bukanda, west of Munyengashi River (Munday 1940: 436-42; 1950: 3-24; 1961: 8-18).

Such myths do not constitute a plausible historical record. Yet it is interesting to note that Verbeek's Lala informants were unable to trace any clear connection between Chipimpi and the Lala and Aushi, had no knowledge of Chisenga Mushili and five other characters in Munday's genealogy, and were unfamiliar with many of the Lamba Chipimpi myth's central episodes, characters, and clans. They explicitly said it is a Lamba story. By contrast, none of the Lamba versions of this myth mention the Lala or their Vulva clan. There is, then, no particular reason to believe the Mushilis' claims of a common ancestry (Verbeek 1987: 239, 248-49). Nor is there any reason to believe that the Lamba's Hair clan belongs with the Lala's set of vulgar sister-clans. Given their limited distribution, it is far more likely that the Vulva and its vulgar sister-clans are specific to and originated among these Lala.

There are a number of more or less plausible reasons for the association between the Hair and Vulva clans. First, the mishishi (head hair) of the Bena Mishishi is certainly a euphemism for pubic hair (Doke 1931: 194; Stefaniszyn 1964b: 92), and the scandalous fable of how this clan was outcast from the Vulva clan plays upon this semantic ambiguity. In effect, this unlikely story degrades the Hair clan: first, by suggesting that they derive from an earlier, more legitimate chiefly clan; and second, by reducing them to the status of the Vulva's other vulgar sister-clans.

That some Lamba might entertain such vulgar notions about their chiefs is aptly demonstrated in two remarkable versions of the Chipimpi myth recorded by Verbeek (1982: 38-41, 54-59). It seems that Lesa (God) separately sent Kashanga and Chipimpi, or their parents, out of Kola to find their land. The woman left with her firesticks and seeds. The man was given their genitals in two bundles, but, offended by its smell, tossed Kashanga's bundle by the way. No sooner did they meet when, like joking-clan partners, they began arguing over who was whose chief. Their bantering continued long after Kashanga retrieved her bundle and they put on their genitals. Chipimpi got a huge erection, but Kashanga refused him and berated him for his penis which, waking or sleeping, continuously (and contemptuously) spat "saliva" at her. Kashanga relented after accepting an axe in tribute, but she warned Chipimpi that he would never be her master, and would always have to beg and pay to sleep with her.

The antagonism between the mythical couple in this episode not only reflects the matrilineal war between the sexes, and the subsequent triumph of the Hair over the Goat clan, but is just the sort of banter one might expect from an encounter between the Lala's vulgar sister-clans.

In addition to their sexual sense of humor, the Lamba also have a healthy disregard for unbearably proud chiefs, and share the common Central African tales of the villagers who killed their tyrannical chief in a pit of boiling beer or water, and of the foolish chief who tried to catch the moon with a bamboo Tower of Babel (Doke 1927: 15, 277-79). Commoners, as their chief's "slaves," should show their respect with tribute, 
gifts, and decorous speech. But the chief must also respect and be generous to his "children" lest they abandon him to be chief over all the trees (Doke 1927: 429, 476, 48990, 509). Thus Lamba commoners presumably perpetuate the association between head and pubic hair to subvert the Hair clan's royal pretensions. I suspect this is what Lamba commoners mean when, in confidence, they claim that the Hair and Vulva clans are related.

The most compelling reason for this association between head and pubic hair and the Hair and Vulva clans is to be found in the Lamba-Lala encounters of the nineteenth century, when the Vulva clan chiefs expanded their territory in all directions and, in the west, conquered the Lamba peoples of Bukanda (Verbeek 1987: 249-52, 311). The Lala say that this easternmost end of the Pedicle is so rich in honey, mushrooms, and wild fruits that its residents need never fear famine (Lambo 1946: 233). It is no accident that the Lamba and Lala chiefdoms in Bukanda contain a generous mix of both Lala and Lamba residents (Boone 1961: 96-103; Lambo 1943: 26-27), for in the middle 1800s the Vulva clan chiefs extended their control to the west of the Munyengashi River, the present ethnic boundary. It was only around 1900 that the Belgians reestablished the Munyengashi boundary, and they did so after a Lala chief went to war (Lambo's [1946: 236] "revolt") on the disloyal Lamba villages that refused to help fill his food and rubber levies (Verbeek 1987: 229, 252-58, 264-67).

Yet this association between the Hair and Vulva clans is much more than yet another example of a joking-relationship between peoples who formerly warred upon each other (Mitchell 1956: 35-42). For it seems that the Mushili lineage of the Lala's Vulva clan chiefs, the one that claims common mythical ties to the Lamba and Aushi chiefs, appropriated the Lamba myth of Chief Chipimpi to mask their late nineteenth century misfortunes, and to preserve the memory of their former rule. For the Mushili lineage in Shaba fell from power in the early 1900s when, following Chief Mushili's death, the Belgians awarded his chiefdom to their appointed go-between from a different Vulva clan lineage (Verbeek 1987: 240-44, 256-58, 263).

The territory of Chief Mushili's Vulva clan lineage was usurped by the same Chief Namopala who, with neighboring Chief Mufumbi, was deposed and died in prison for hosting Tomo Nyirenda (Mwana Lesa), the Watchtower prophet, and for concealing the latter's murder of at least forty-eight "witches" during his 1925 tour of Katanga. Like Lala Chief Shaiwila, just below the border, neither Namopala nor Mufumbi were wholly legitimate chiefs, and a number of these "witches" are known to have opposed their rule (Verbeek 1977: 89-94; 1983: 37-108; 1987: 258-63). The Mushili lineage, as stated earlier, did stay in power among the Western Lala and Ambo chiefdoms in Zambia's Mkushi and Petauke Districts.

The other misfortunes center upon the chiefdom of Mushili's mother, Ngosa Mupeta, on the western (i.e., Lamba) side of the Munyengashi. Her nickname, Nabayeke (Mother of the Yeke), refers to the Yeke occupation of the early 1870s, when the Lala chiefs in Bukanda submitted to the Yeke. Ngosa Mupeta then married a Yeke of the Goat clan. Then, during the Aushi invasion of the late 1880s, her youngest daughter, 
Musonda Kaseba, was taken hostage and disappeared across the Luapula. Though Ngosa Mupeta's second husband, Mumbilima the elephant hunter, shared the usual occupational reputation for witchcraft, they are supposed to have lived in brotherly and sisterly harmony, for both came from chiefly clans. Mumbilima, who succeeded her upon her death, was a Lamba from the Hair clan, and her chiefdom, now that of Chief Kumbwa, has remained in control of the Lamba's Hair clan every since (Lambo 1943: 27-28; Verbeek 1987: 12, 49-50, 254-56, 274-76).

It is the history of Ngosa Mupeta's chiefdom that best explains the tie between the Lamba's Hair clan and the Lamba and Aushi chiefs. For, as in Munday's Western Lala version of the Chipimpi myth, her daughter, Musonda Kaseba of the Vulva clan, did cross the Luapula as an Aushi hostage to live among the chiefs of the Wild Pig clan. Presumably it is this same Musonda who appears with Ngosa Mupeta in a Western Lala list of ancestresses as "Nampongela [literally, 'I have lost myself'], alias Musonda, who appears to have been of the least significance," and whose "offspring [kin] . . . are [were among] the Lala chiefs in Congo territory" (Moffat Thomson, in Brelsford 1965: 49-50). And just as in the Western Lala's Chipimpi myth, the Mushili lineage really did lose its rule in Bukanda after Ngosa Mupeta's chiefdom passed from the control of her and her Goat clan husband to that of the Hair clan chiefs.

There is no evidence to indicate that the Lamba's Hair clan began or belongs with the Lala's Vulva and its vulgar sister-clans. Yet its name is ambiguous, and Lamba commoners enjoy and perpetuate its scandalous implications. While the symbolic opposition of joking-clan partners goes a long way in explaining this association between the chiefly Hair and Vulva clans, it probably derives from the nineteenth century rivalry between the Bukanda Lamba and Lala chiefs, and, as symbolized in the myth of Chief Chipimpi, from the consequent redemption of Ngosa Mupeta's chiefdom by her Hair clan successors. There is power in myth and symbols, but it is particularly satisfying to show how such constructs seem to reflect equally real historical struggles for legitimacy and power.

\section{$\underline{\text { References }}$}

Boone, O. 1961. Carte ethnique du Congo: Quart sud-est. Annales, sciences humaines 37. Tervuren: Musée Royale de l'Afrique Centrale.

Boswell, D. M. 1969. Personal crises and the mobilization of the social network. In Social Networks in Urban Situations, edited by J. C. Mitchell, 245-96. Manchester: Manchester University Press.

Brelsford, W. V. 1965. The Tribes of Zambia, 2nd ed. Lusaka: Government Printer. 
Burton, R. F. 1873. The Lands of Cazembe: Lacerda's Journey to Cazembe in 1798, translated and annotated by R. F. Burton. London: Royal Geographic Society.

Cunnison, I. 1959. The Luapula Peoples of Northern Rhodesia. Manchester: Manchester University Press.

Doke, C. M. 1922. A specimen of the folk-lore of the Lamba people of Northern Rhodesia. Bantu Studies 1: 30-37.

-----. 1927. Lamba Folk-Lore. New York: G. E. Stechert.

-----. 1931. The Lambas of Northern Rhodesia. London: G. G. Harrop.

-----. 1963. English-Lamba Vocabulary, 2d rev. ed. Johannesburg: Witwatersrand University Press.

Edme, P. [E. Bourgeois] 1944. Nkoya Kalambwa: Scènes de la vie noire. Elisabethville: Editions Congolaises.

Epstein, A. L. 1981. Urbanization and Kinship. New York: Academic Press.

Grévisse, F. 1956-58. Notes ethnographiques relatives à quelques populations autochtones du Haut-Katanga industriel. Bulletin du Centre d'Etudes des Problèmes Sociaux Indigènes 32-41.

Lambo, L. 1943. Organisation judiciare et procedure du tribunal coutumier de Kumbwa. Bulletin de juridictions indigenes et du droit coutumiers congolais 11 (2): 26-30.

-----. 1946. Etude sur les Balala. Bulletin des juridictions indigenes et du droit coutumiers congolais 14 (8): 231-56, (9): 273-300, (10): 313-46.

Long, N. 1968. Social Change and the Individual. Manchester: Manchester University Press.

Marchal, R. 1933-34. Moers et croyance des Balamba. Bulletin des juridictions indigenes et du droit coutumier congolais 1 (4): 62-66, (5): 82-86, (6): 103-06, (7): 124-27, (8): 153-55.

Mitchell, J. C. 1956. The Kalela Dance. Rhodes-Livingstone Paper No. 27. Manchester: Manchester University Press.

Mitchell, J. C., and J. A. Barnes. 1950. The Lamba Village: Report of a Social Survey. African Studies Communication No. 24. University of Cape Town.

Munday, J. T. 1940. Some traditions of the Nyendwa clan of Northern Rhodesia. Bantu Studies 14: 435-54.

-----. Inyendwa (W. Lala-Maswaka Traditions), 3d ed. Cilala: Lovedale Press.

-----. Kankomba. Central Bantu Historical Texts I, Part I, Rhodes-Livingstone Communication No. 22. Lusaka: Rhodes-Livingstone Institute. 
Richards, A. I. 1937. Reciprocal clan relationships among the Bemba. Man 37: 188-93.

-----. 1939. Land, Labour, and Diet in Northern Rhodesia. Oxford University Press.

-----. 1940. Bemba Marriage and Present Economic Conditions. Rhodes-Livingstone

Paper No. 4. Manchester: Manchester University Press.

----. 1950. Some types of family structure amongst the Central Bantu. In African Systems of Kinship and Marriage, edited by A. R. Radcliffe-Brown and D. Forde, 207-51. London: Oxford University Press.

Siegel, B. 1985. The binary mind and the immortal head: A structural analysis of the myth of Chief Chipimpi. Furman Studies 31 (December): 36-55.

Slaski, J. 1950. Peoples of the Lower Luapula Valley. Ethnographic Survey of Africa, East Central Africa, Part II. London: International African Survey.

Smith, E. W., and A. M. Dale. 1920. The Ila-Speaking People of Northern Rhodesia, 2 vols. London: Macmillan.

Stefaniszyn, B. 1950. Funeral friendship in Central Africa. Africa 20: 290-306.

-----. 1964a. The Material Culture of the Ambo of Northern Rhodesia. RhodesLivingstone Museum Occasional Paper No. 16. Manchester: Manchester University Press.

-----. 1964b. Social and Ritual Life of the Ambo of Northern Rhodesia. London: Oxford University Press.

Stephenson, J. E. 1937. Chirupula's Tale. London: Geoffrey Bles.

Verbeek, L. 1977. Kitawala et détecteurs de sorciers dans la Botte de Sakania (19251975). Enquêtes et documents d'histoire africaine 2: 86-107.

----. 1982. Mythe et culte de Kipimpi (Rep. du Zaire). Series 2, vol. 80. Bandundu: CEEBA Publications.

-----. 1983. Mouvements religieux dans la région de Sakania (1925-1931). Enquêtes et documents d'histoire africaine 5.

----. 1987. Filiation et usurpation: Histoire socio-politique de la region entre Luapula et Copperbelt. Annales, sciences humaines 123. Tervuren: Musée Royal de l'Afrique Centrale.

Watson, W. 1954. The Kaonde village. Rhodes-Livingstone Journal 15: 1-30.

White Fathers. 1954. The White Fathers' Bemba-English Dictionary, rev. ed. Cape Town: Longmans, Green.

Whiteley, W. 1954. Bemba and Related Peoples of Northern Rhodesia. Ethnographic Survey of Africa, East Central Africa, Part II. London: International African Institute. 